\title{
MINERALOGICAL AND ORE PETROGRAPHIC COMPARISON OF GEDABEY AND GADIR DEPOSITS IN GEDABEY REGION (WESTERN AZERBAIJAN)
}

\author{
İsmayıl C. ${ }^{1}$, Arık F. ${ }^{2}$, Özen Y. ${ }^{3}$ \\ ${ }^{1}$ Konya Technical University, Ph.D. student of Geological Engineering Department \\ Ardychly quarter, Rauf Orbay str., Selchuklu district, Konya, Turkey, \\ 42250: cosqun.ismayil1993@gmail.com; \\ ${ }^{2}$ Konya Technical University, Prof.Dr. Head of Geological Engineering Department \\ Ardychly quarter, Rauf Orbay str., Selchuklu district, Konya, Turkey, 42250; \\ ${ }^{3}$ Konya Technical University, Dr. of Geological Engineering Department \\ Ardychly quarter, Rauf Orbay str., Selchuklu district, Konya, Turkey, 42250
}

Keywords: Porphyryepithermal, $\mathrm{Au}-\mathrm{Ag}-\mathrm{Cu}-\mathrm{Pb}$ Zn deposit, Gadir, Gedabey, Lesser Caucasus
Summary. Gedabey (Western Azerbaijan) mine province is located in the Lesser Caucasus region of Tethys metallogenic belt, which is one of the most important metallogenic provinces of the world. Mineralization occurred in the subduction zone within the Lok-Karabakh structuralformation zone of the Lesser Caucasus. The Gedabey ore province is one of the main producing mining of the Gedabey ore district in Azerbaijan and is the largest porphyry-epithermal ore zone of the country. Volcanic rocks and the Gedabey intrusive, which indurated these volcanic rocks, play an important role in the formation of mineralizations in the region. According to previous studies the volcanic rocks containing rhyolite and rhyodacite in the Gedabey ore region are Bajocian age, andesite tuffs and andesite dacites are Bathonian age, diorite and granodiorite within Gedabey intrusive are Upper Jurassic - Lower Cretaceous age. The magmatism of the Gedabey ore region is divided into 3 stages: Bajocian stage, Bathonian stage and Upper Jurassic stage. The GedabeyBittibulag fracture is the most important deeper fault in the region, which ore-controls both the Gedabey $\mathrm{Au}-\mathrm{Ag}-\mathrm{Cu}$ and the Gadir $\mathrm{Au}-\mathrm{Ag}-\mathrm{Cu}-\mathrm{Pb}-\mathrm{Zn}$ deposits within the Gedabey region.This study aims to compare the mineralogical-petrographical features and hydrothermal alteration zones of Gedabey Au-Ag-Cu and Gadir $\mathrm{Au}-\mathrm{Ag}-\mathrm{Cu}-\mathrm{Pb}-\mathrm{Zn}$ deposits by means of petrography, ore petrography and X-ray diffraction methods. Chalcopyrite, sphalerite, galena, pyrite, gold, covellite, malachite, azurite were commonly observed in these mineralizations.

(C) 2020 Earth Science Division, Azerbaijan National Academy of Sciences. All rights reserved.

\section{INTRODUCTION}

Gedabey ore district which is one of the world's major gold and copper ore districts in the Lesser Caucasus is located in the Tethys Metallogenic Belt extending to Turkey from Pakistan, Iran, Azerbaijan and Georgia (Fig. 1).The processing of copper ores is being carried out in numerous ancient copper mines such as Gedabey, Allahverdi, Shamlık, Mishana, Zangazur and Shanardara regions in Azerbaijan. The mining activities in Gedabey ore district started 2000 years ago, and the Ottoman and Azerbaijani Khanates handled the rich copper occurrences by changing hands after the first settlers (Singer et al., 2008).
The Gedabey Au-Ag-Cu and Gadir $\mathrm{Au}-\mathrm{Ag}-\mathrm{Cu}-$ $\mathrm{Pb}-\mathrm{Zn}$ deposits are located around the axis of the Shamkir anticlinorium in the western part of the Dashkesan synclinorium in the Lok-Aghdam region of the Lesser Caucasus (Veliyev et al., 2018; İsmay1 et al., 2018). The Gedabey $\mathrm{Au}-\mathrm{Ag}-\mathrm{Cu}$ deposit is commonly observed in the east, northeast and southeastern slopes of the Misdağ Mountain. The Gadir $\mathrm{Au}-\mathrm{Ag}-\mathrm{Cu}-\mathrm{Pb}-\mathrm{Zn}$ deposit located in Yoğundağ epithermal system in the south of Gedabey ore district was discovered by Gedabey Exploration Group (GEG) and geological consultant Allahverdi Agakishiyev in 2012. The Gadir Au-Ag-Cu-Pb-Zn deposit is located approximately $370 \mathrm{~m}$ from Gedabey $\mathrm{Au}-\mathrm{Ag}-\mathrm{Cu}$ deposit. 


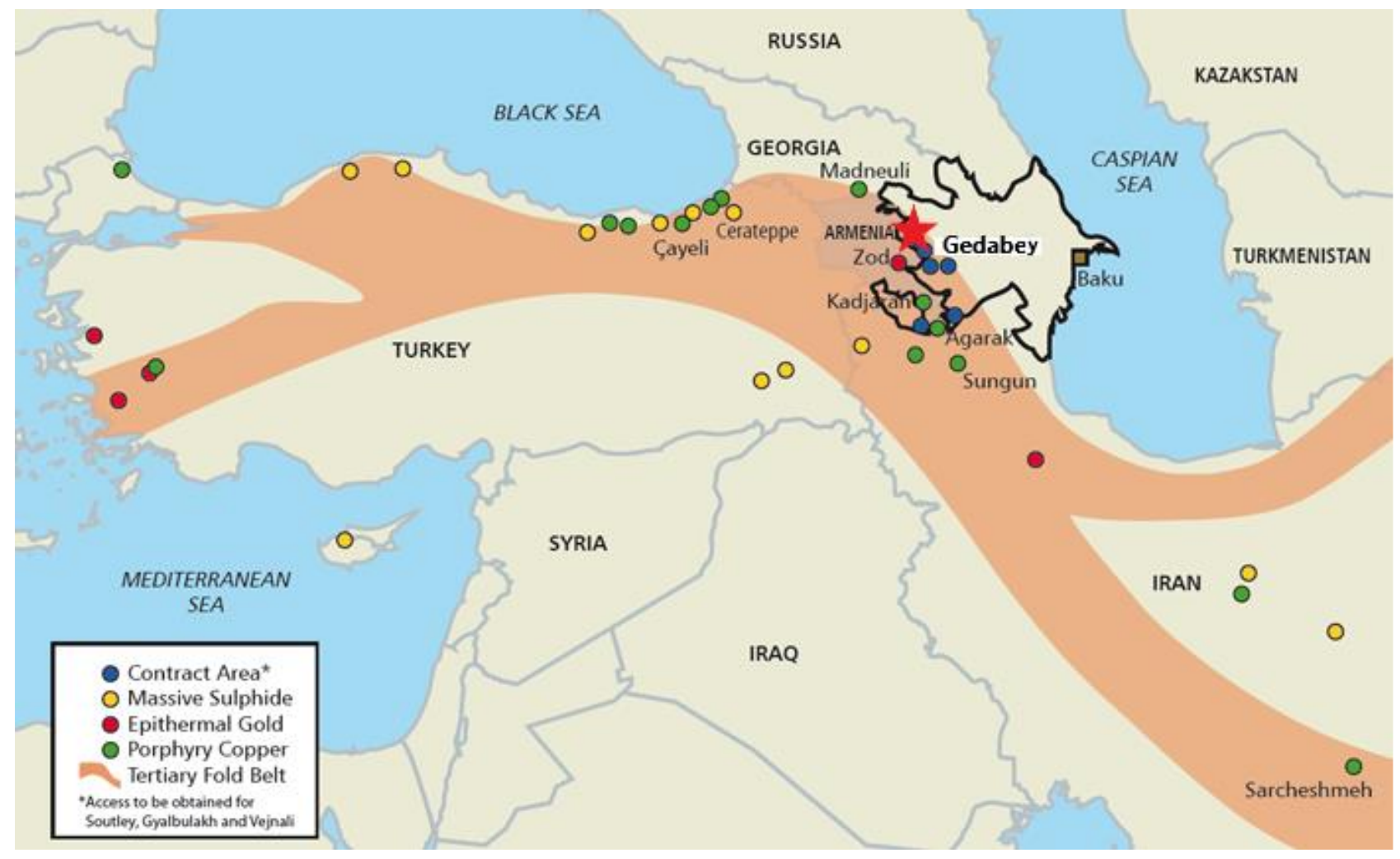

Fig. 1. Porphyry-epithermal deposits in Tethyan Metallogenic Belt (modified from https://www.angloasianmining.com/operations/overview/)

Yoğundağ Mountain is a porphyry-epithermal zone, with known deposits in the area (e.g.Gadir, Gedabey, Umid and Zefer) believed to represent the upper portion of the mineralizing system. The Gadir and Gedabey ore deposits are located within the large Gedabey-Garadag volcanic-plutonic system. This volcanic-plutonic system is characterised by a complex internal structure indicative of repeated tectonic movement and multi-cyclic activity (Bayramov, 2015; İsmay1l, 2019; Anglo Asian Mining PLC, 2019).The province is very complex due to the tectonic structure of the Gedabey region and the Shamkir anticline (Babazadeh et al., 2015). Gedabey Au-Ag$\mathrm{Cu}$ and Gadir $\mathrm{Au}-\mathrm{Ag}-\mathrm{Cu}-\mathrm{Pb}-\mathrm{Zn}$ mineralizations are structurally controlled. The ore deposits of the Gedabey district are controlled by a deep-seated, NS oriented, orogen-transverse arc-shaped fault (Баба-заде и др., 1990). The Gadir and Gedabey ore body, which has a complex geological structure, contains intrusive rocks of different ages and compositions. Three sets of regional fault zones controlling mineralization have been identified and are characterised on the basis of strike direction and morphological characteristics: 1-NW-SE striking faults (e.g. GedabeyBittibulag Deep Fault, Misdag Fault), 2 -NE-trending faults (e.g. Gedabey-Ertepe Fault, Gerger-Arykhdam Fault, Gadir ore-controlling faults), 3 - local transverse faults (Bayramov, 2015; İsmay1l, 2019; Anglo Asian Mining PLC, 2019).
The magmatic activities in the region have been occurred in Bajocian-Bathonian (Middle Jurassic) and Early Cretaceous (Fig. 2; Bayramov, 2015). In the Gedabey district the plutonic rocks consist of Upper Jurassic - Lower Cretaceous aged gabbro, gabbronorite, diorite, granodiorite, and quartz-diorite; volcanic rocks contain Bajocian and Bathonian aged andesite, andesite lava, andesite porphyry, rhyolite and rhyodacitic volcanic rocks (Керимов, 1963; İsmay1l, 2019). In addition, alluvial sediments on the Gedabey $\mathrm{Au}-\mathrm{Ag}-\mathrm{Cu}$ deposit and silicification on the Gadir mineralization are observed (Veliyev et al., 2018).The deposits are genetically related with Gedabey intrusion (its quartz-diorite phase; Bayramov, 2016).

Late Jurassic - Early Cretaceous was dated for Gedabey diorite, granodiorite and subsidiary aplites (K-Ar; from 129-142 Ма to $150 \mathrm{Ma}$; Исмет и др., 2003), and $144 \pm 1$ Ma for quartz-diorite (U-Pb; Late Jurassic-Early Cretaceous; Садыхов и др., 2018). The Gedabey $\mathrm{Au}-\mathrm{Ag}-\mathrm{Cu}$ deposit is commonly observed in the east, northeast and southeastern slopes of the Misdağ Mountain. The Gadir Au-Ag-Cu-Pb-Zn deposit is in the east of Yoğundağ Mountain, near Gedabey Au$\mathrm{Ag}-\mathrm{Cu} \pm \mathrm{Zn}$ deposit. The mineralizations are represented by the quartz-porphyry body localized between subhorizontal andesite at the west and a diorite intrusion at the east. The quartz-porphyry intrusive rocks host gold mineralization in Gedabey and Gadir deposits (Novruzov et al., 2019). The Gadir mineralization was con- 
trolled by NW-SE faults. The faulting occurred in contact between the andesitic tuff and quartz porphyry. Au in the Gadir deposit is mainly hosted by intrusive bodies dominated by quartz porphyry. The host rocks were commonly altered by propylitic alteration, primarily in andesitic tuff (Novruzov et al., 2019). The Gedabey $\mathrm{Au}-\mathrm{Ag}-\mathrm{Cu}$ deposit occurred in the quartz porphyry which was formed at the contact of the Middle Jurassic andesitic rocks and the Lower Cretaceous granitoid (granodiorite-diorite).

This study aims to investigate and compare mineralogical-petrographical characteristics and hydrothermal alteration zones of Gedabey $\mathrm{Au}-\mathrm{Ag}-\mathrm{Cu}$ and Gadir $\mathrm{Au}-\mathrm{Ag}-\mathrm{Cu}-\mathrm{Pb}-\mathrm{Zn}$ deposits by means of petrography, ore petrography and $\mathrm{X}$-ray diffraction methods.

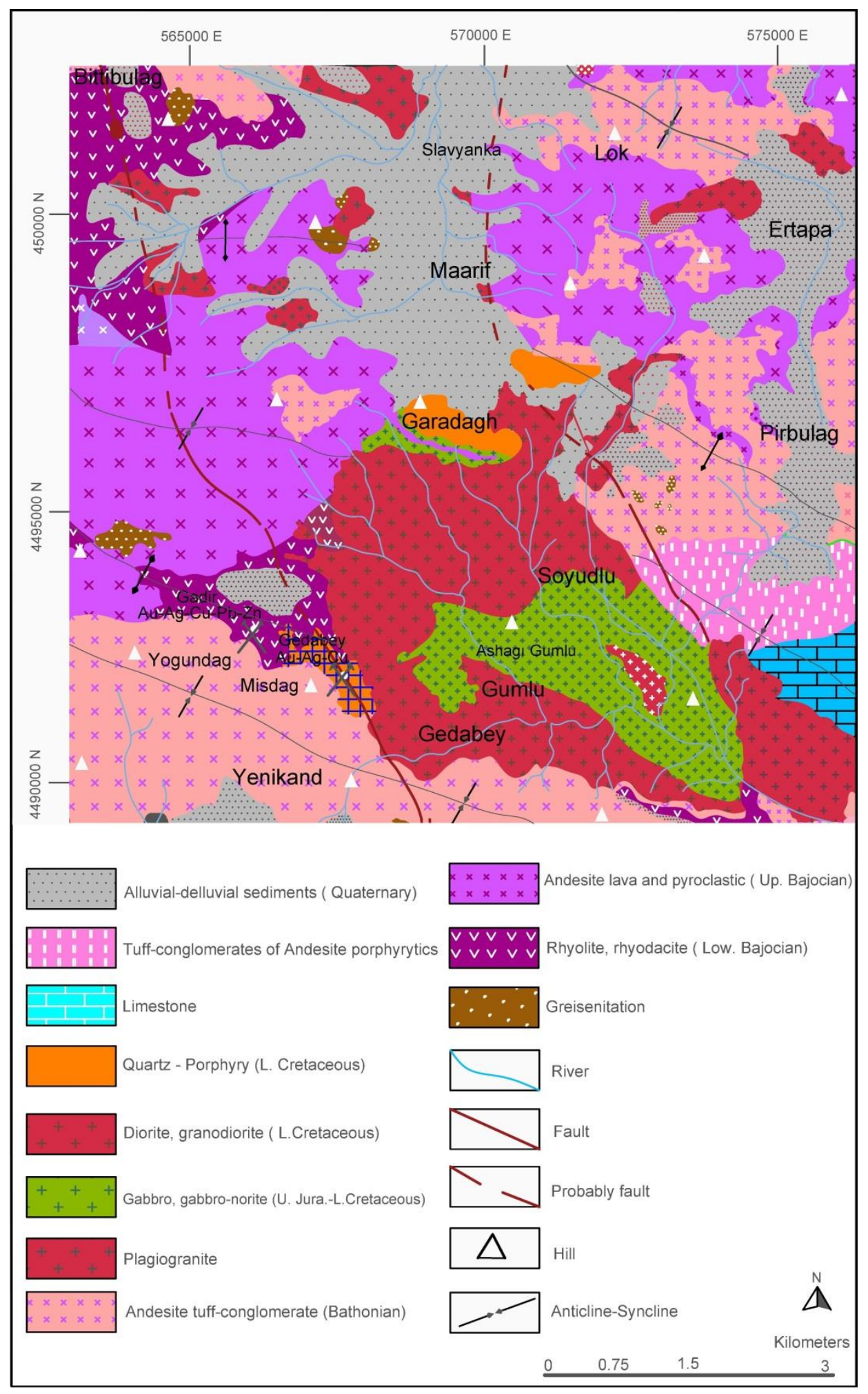

Fig. 2. The geological map of Gedabey ore district (modified from Bayramov, 2015) 


\section{MATERIAL AND METHOD}

The field studies were realized, and outcrop and drill core samples (ore, wall rock, hydrothermal alteration samples) were collected from Gedabey and Gadir deposits in Gedabey ore district (Fig. 3).

Polished sections were prepared in the Seljuk University SÜKOP Gemstone Atelier for the determination of mineralogical and petrographic properties of the collected samples (Fig. 4a,b). Thin sections were prepared in the Pamukkale University Laboratory (Fig. 4c,d). Thin sections and polished sections were examined under Leica DM2700P microscope in Geological Engineering Department in Konya Technical University (Fig. 3 and Fig. 4). In order to carry out more detailed mineralogical research of the samples, XRD analyzes were performed in the mineralogical and petrographic research laboratory of the General Directorate Mineral Research and Exploration (MTA).

\section{RESULT}

\subsection{Gedabey Au-Ag-Cu deposit}

According to petrographical and mineralogical analyses of the samples, potassic, phyllic, advance argillic and propylitic alterations were determined in the Gedabey Au-Ag-Cu deposit. The Gedabey Au$\mathrm{Ag}-\mathrm{Cu}$ mineralization occurred in the quartz porphyry which was formed at the contact of the andesitic rocks and granitoid. The hydrothermal alterations associated with Gedabey $\mathrm{Au}-\mathrm{Ag}-\mathrm{Cu}$ mineralization are phyllic and advanced argillic alterations.

\subsubsection{Petrography}

Plagioclase, biotite, amphibole, chlorite, quartz, and opaque minerals were observed in diorite of the Gedabey granitoid (Fig. 5d). Andesite is composed of amphibole, plagioclase, chlorite, and pyrite (Fig. 5b). Potassic alteration sample collected from drill core is composed of K-feldspar, biotite, and quartz. Sericite, pyrite, quartz and barite were observed in the phyllic alteration (Fig. 5a,c). Kaolinite, alunite, pyrophyllite, barite, quartz, sericite, pyrite were identified in advanced argillic alteration. Propylitic alteration composed of chlorite, epidote, calcite, pyriteand quartz.

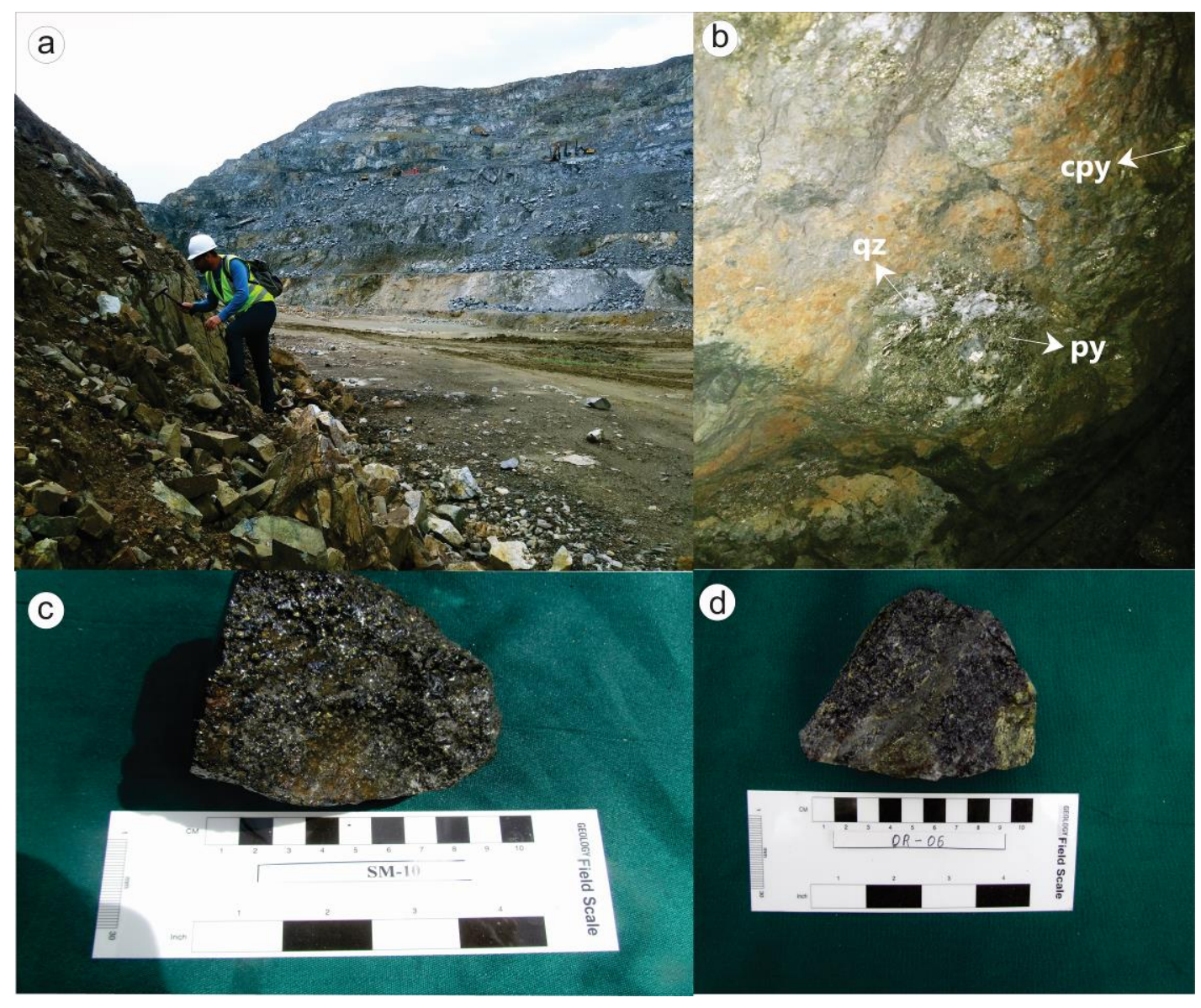

Fig. 3. (a) Open pit and (c) hand sample from Gedabey Au-Ag-Cu deposit, (b)Pyrite (py), chalcopyrite (cpy) and quartz (qz) in underground mining, (d) hand sample from Gadir $\mathrm{Au}-\mathrm{Ag}-\mathrm{Cu}-\mathrm{Pb}-\mathrm{Zn}$ deposit 


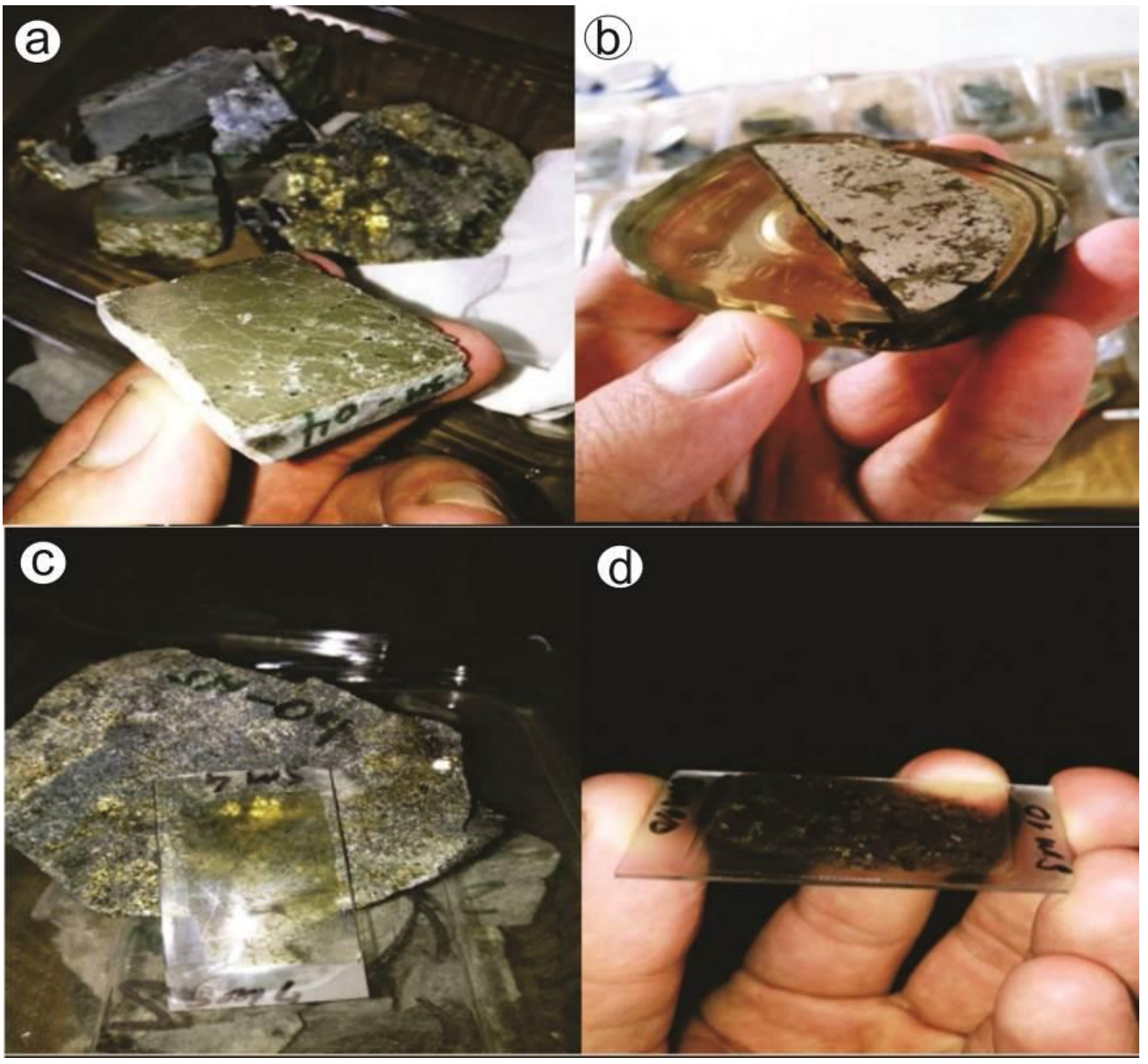

Fig. 4. Polished sections (a,b) and thin sections (c,d) from collected samples

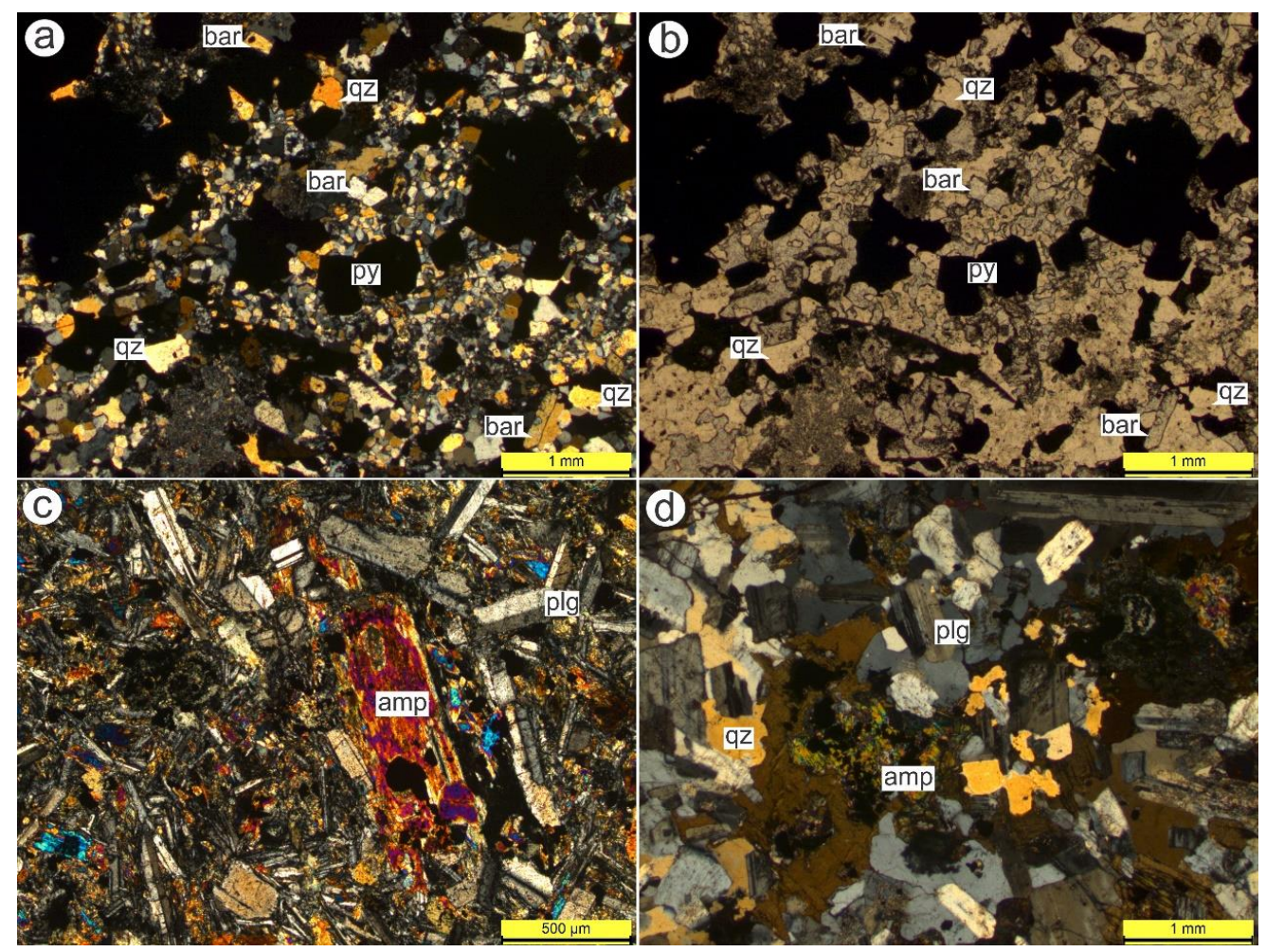

Fig. 1. (a-b) Sericite (ser), pyrite (py), barite (bar), quartz (qz) observed in petrographic studies of phyllic alteration, and (c) amphibole (amp) and plagioclase (plg) in andesite, and (d) amphibole (amp), plagioclase (plg) and quartz in diorite in Gedabey Au-Ag-Cu deposit (a,c,d: $+\mathrm{N}, \mathrm{b}: / / \mathrm{N})$ 


\subsubsection{Ore petrography}

In the Gedabey Au-Ag-Cu mineralization chalcopyrite, sphalerite, galena, pyrite, magnetite, hematite, bornite, molybdenite and enargite were determined by ore microscopy studies as the main ore minerals. Covellite, chalcocite, malachite, goethite, limonite were identified as secondary ore minerals (Fig. 6). The gangue minerals are quartz, calcite and barite in Gedabey $\mathrm{Au}-\mathrm{Ag}-\mathrm{Cu}$ mineralization.
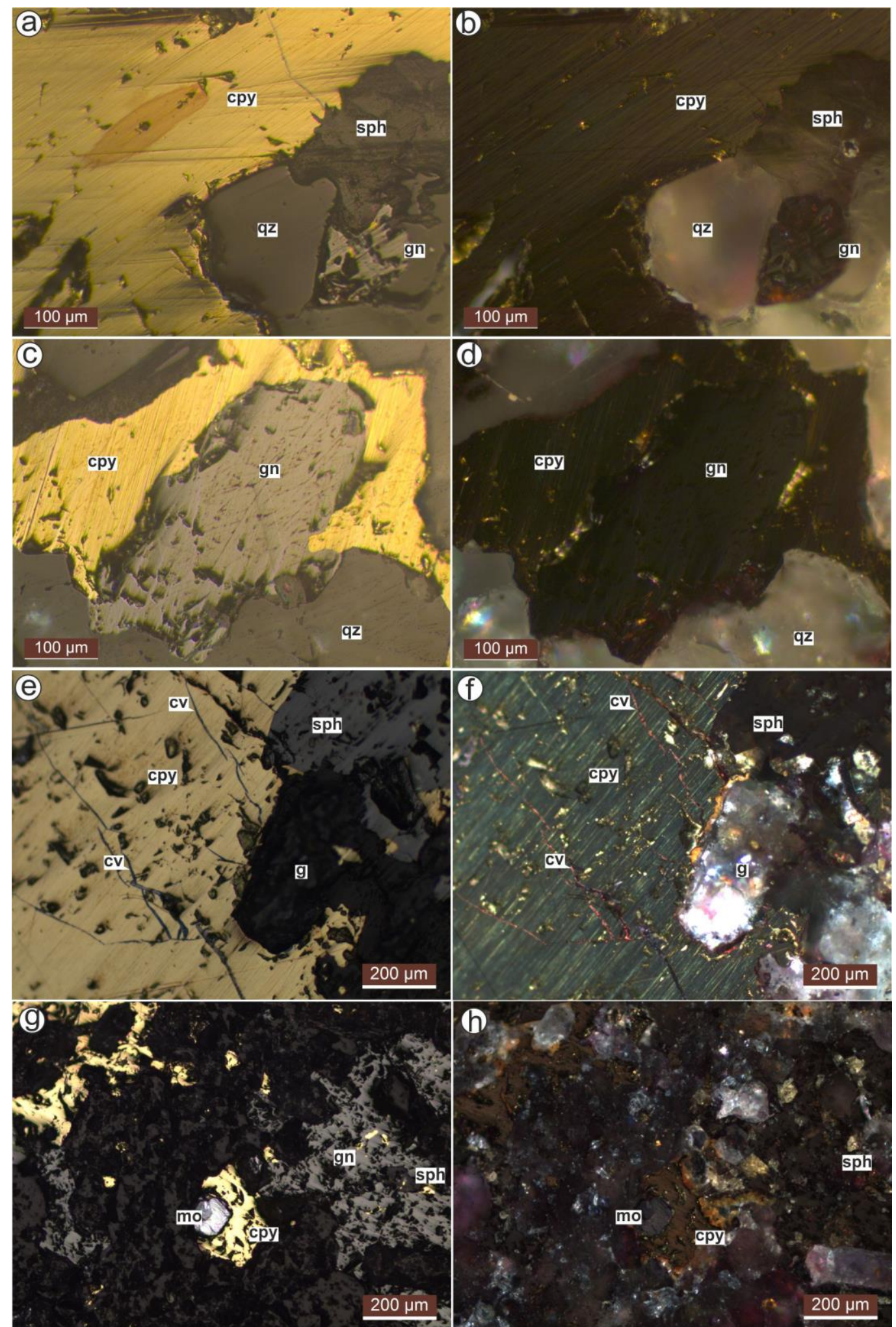

Fig. 6. Chalcopyrite (cpy), molybdenite (mo), sphalerite (sph), galena (gn), pyrite (py), covellite (cv), quartz (qz) in Gedabey Au-Ag-Cu deposit; a,c,e,g: //N, b,d,f,h: +N) 


\subsubsection{X-Ray Diffraction}

Chalcopyrite, pyrite, sphalerite, magnetite, chlorite, K-feldspar, sericite, sodalite, wurtzite, plumbotellurite, kaolinite, alunite, illite, siderite, phlogopite, quartz and epidote were determined by XRD analy- sis of samples collected from Gedabey ore deposit. Sericite, pyrite and quartz were identified in the phyllic alteration (Fig. 7a). Kaolinite, illite, barite, quartz, sericite, pyrite were determined in advanced argillic alteration.

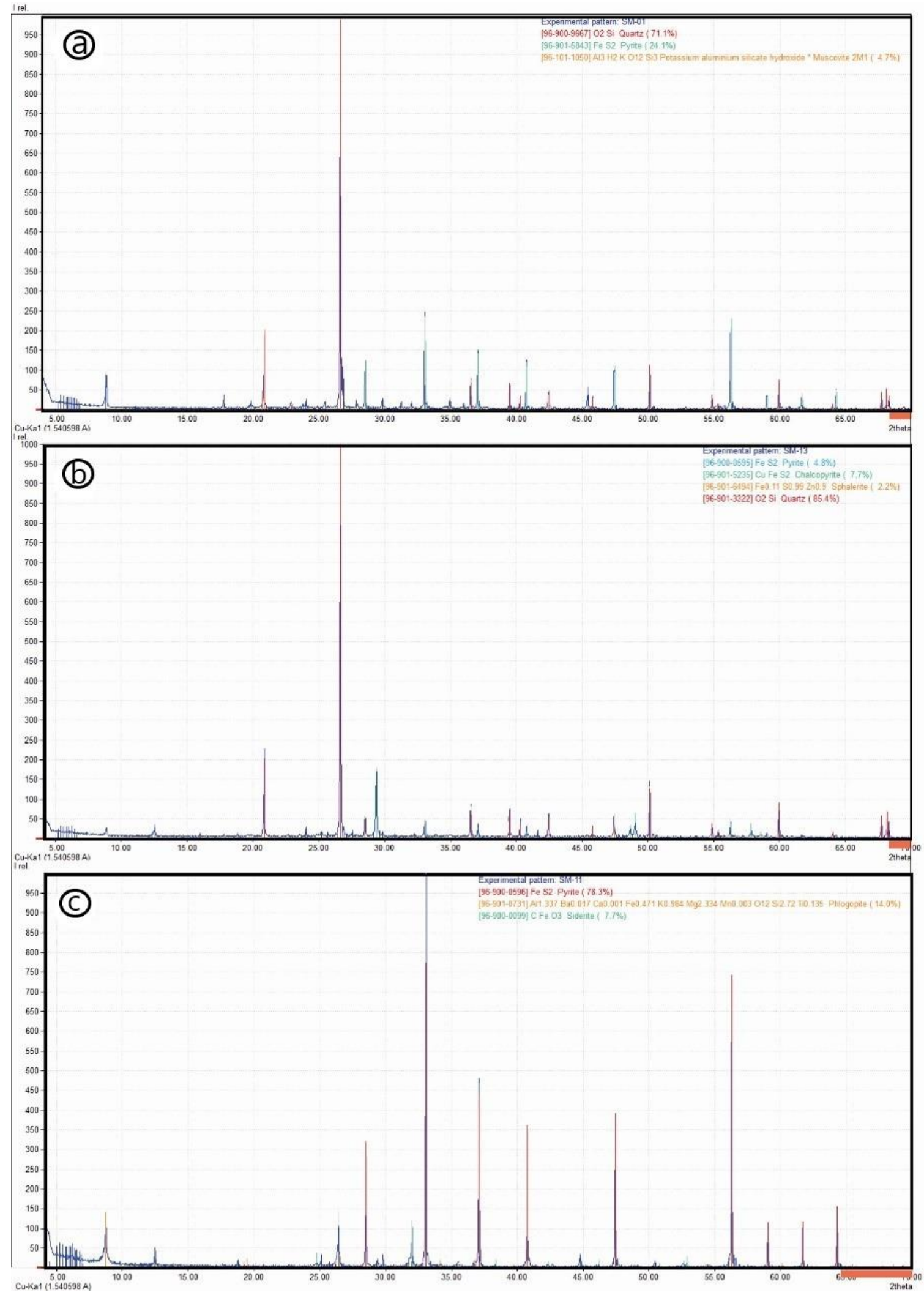

Fig. 7. X-Ray diffractograms of Gedabey Au-Ag-Cu mineralization 


\subsection{Gadir Au-Ag-Cu-Pb-Zn deposit}

The Gadir mineralization occurred in contact of the andesitic tuff and quartz porphyry. The hydrothermal alterations associated with mineralization are quartz \pm adularia \pm sericite and propylitic alterations.

\subsubsection{Petrography}

In petrography studies of andesite collected from field studies in Gadir $\mathrm{Au}-\mathrm{Ag}-\mathrm{Cu}-\mathrm{Pb}-\mathrm{Zn}$ deposit, plagioclase, amphibole, pyroxene, muscovite, hematite, epidote, calcite, sericite, clay minerals and opaque minerals were observed. Amphibole, plagioclase, chlorite were observed in petrographic studies of andesite and andesitic tuff in Gadir $\mathrm{Au}-\mathrm{Ag}-\mathrm{Cu}-$ $\mathrm{Pb}-\mathrm{Zn}$ deposit (Fig.8).

\subsubsection{Ore petrography}

In ore microscopy studies of Gadir $\mathrm{Au}-\mathrm{Ag}-\mathrm{Cu}-$ $\mathrm{Pb}-\mathrm{Zn}$ mineralization, the main ore minerals were chalcopyrite, sphalerite, galena, arsenopyrite, pyrite, hessite and native gold. Sphalerite and chalcopyrite is replaced by galena in some polished sections
(Fig.9e,f). Chalcopyrite is observed as inclusion in sphalerite and galena (Fig. 9c,d,e).

\subsubsection{X-Ray diffraction}

According to the XRD analyses from Gadir $\mathrm{Au}-\mathrm{Ag}-\mathrm{Cu}-\mathrm{Pb}-\mathrm{Zn}$ mineralization, $\mathrm{AuAgTe}_{4}$, tetrahedrite, cordierite, jasper, titanomagnetite, augite, chamosite, muscovite, hematite, epidote, chlorite, sericite, pyrite, sphalerite, galena, magnetite, barite and wurtzite were identified (Fig. 10). Chamosite, epidote, calcite, quartz, sericite, and hematite were defined from propylitic alteration.

\section{CONCLUSION}

Gadir deposit located in the east of Yoğundağ Mountain and Gedabey deposit located in the northeast and southeastern slopes of the Misdağ Mountain are located in the large Gedabey-Garadag volcanicplutonic system characterised by a complex internal structure indicative of repeated tectonic movement and multi-cyclic activity. The Gedabey and Gadir deposits are controlled by $\sim$ NS oriented regional fault zones controlling mineralizations.
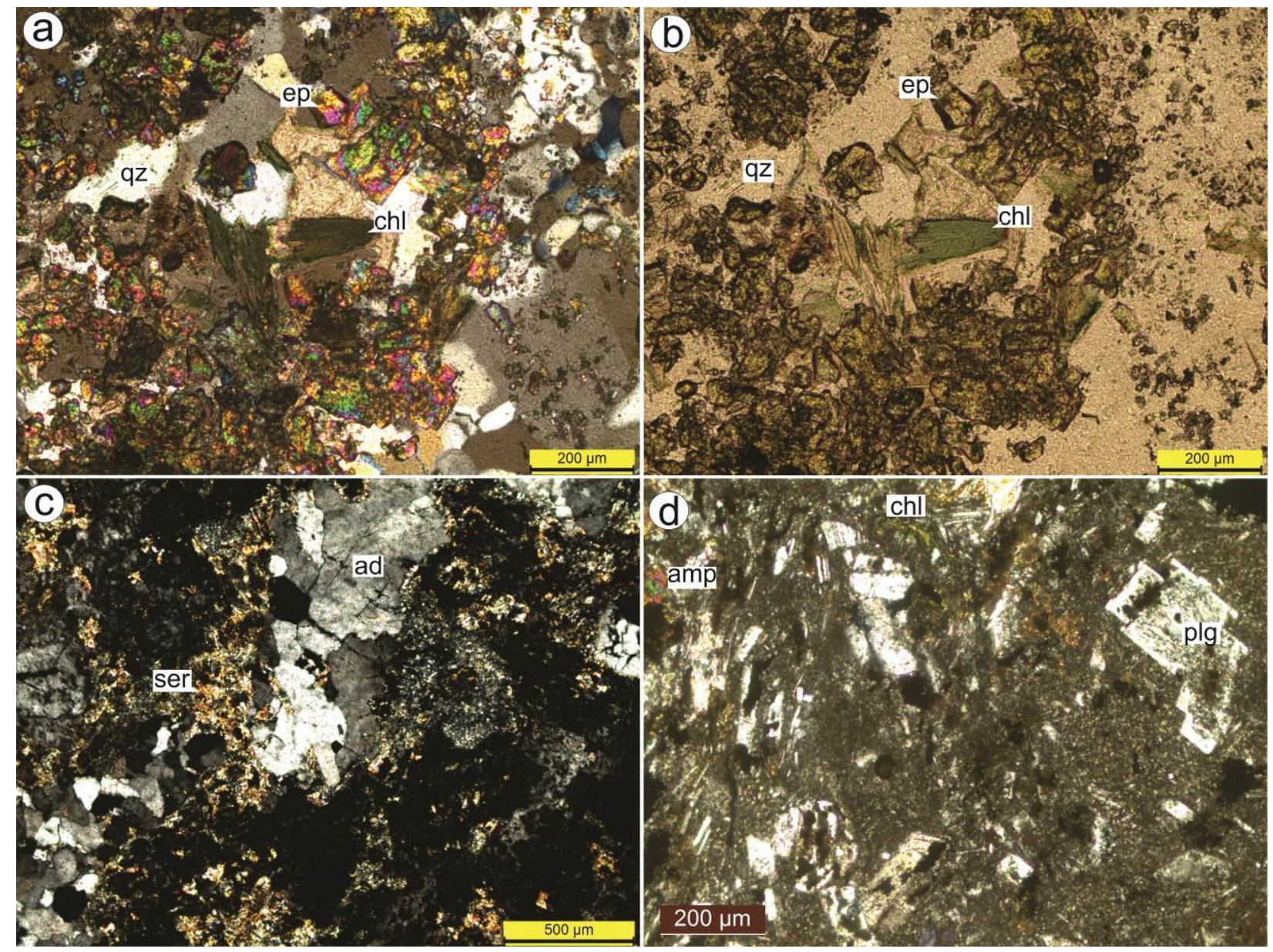

Fig. 8. (a,b) Epidote (ep), chlorite (chl), quartz (qz) in propylitic alteration, (c) adularia (ad) and sericite (ser) (d) amphibole (amp), plagioclase (plg), and chlorite (chl) mineral observed in petrographic studies of andesite and andesitic tuff in $\mathrm{Gadir} \mathrm{Au}-\mathrm{Ag}-\mathrm{Cu}-\mathrm{Pb}-\mathrm{Zn}$ deposit $(\mathrm{a}, \mathrm{b}:+\mathrm{N} ; \mathrm{b}, \mathrm{d}: / / \mathrm{N})$ 


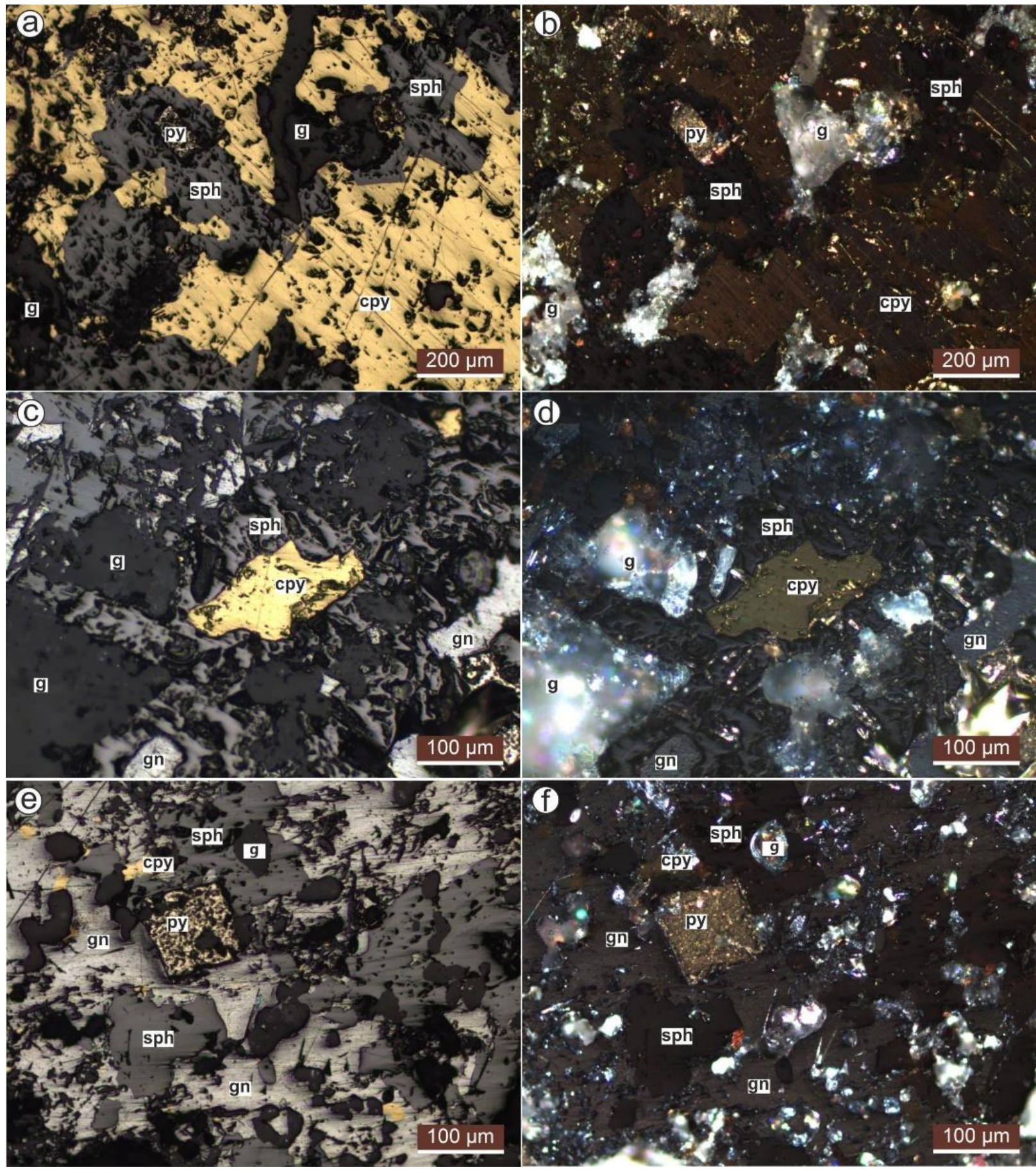

Fig. 9. Pyrite (py), chalcopyrite (cpy), galena (gn), sphalerite (sph), quartz (qz), gangue (g) in GadirAu-Ag-Cu-Pb-Zn mineralization $(\mathrm{a}, \mathrm{c}, \mathrm{e}: / / \mathrm{N} ; \mathrm{b}, \mathrm{d}, \mathrm{f}:+\mathrm{N})$

The Gedabey Au-Ag-Cu deposit occurred in the quartz porphyry formed at the contact of the andesitic rocks and granitoid. The Gadir $\mathrm{Au}-\mathrm{Ag}-\mathrm{Cu}-\mathrm{Pb}-\mathrm{Zn}$ deposit occurred in the contact of the andesitic tuff and quartz porphyry. Chalcopyrite, sphalerite, galena, pyrite, magnetite, hematite, bornite, molybdenite, enargite, covellite, chalcocite, malachite, goethite, limonite, quartz, calcite, and barite were determined in the Gedabey $\mathrm{Au}-\mathrm{Ag}-\mathrm{Cu}$ mineralization. Also chalcopyrite, sphalerite, galena, arsenopyrite, tetrahedrite and pyrite were observed in the Gadir Au-
$\mathrm{Ag}-\mathrm{Cu}-\mathrm{Pb}-\mathrm{Zn}$ mineralization. While gold and silver occured as native gold, electrum, petzite and hessite associated with copper mineralization in Gedabey deposit, native gold and hessite were observed in Gadir deposit. The same hydrothermal alteration zones and similar mineral assemblage were identified in both ore deposit. Potassic alteration represented by biotite, K-feldspar, quartz was observed in drill core samples taken from deep horizons of Gedabey $\mathrm{Au}-\mathrm{Cu}$ deposit. The phyllic alteration is represented by sericite, pyrite and quartz in the region, 
Geology and geophysics
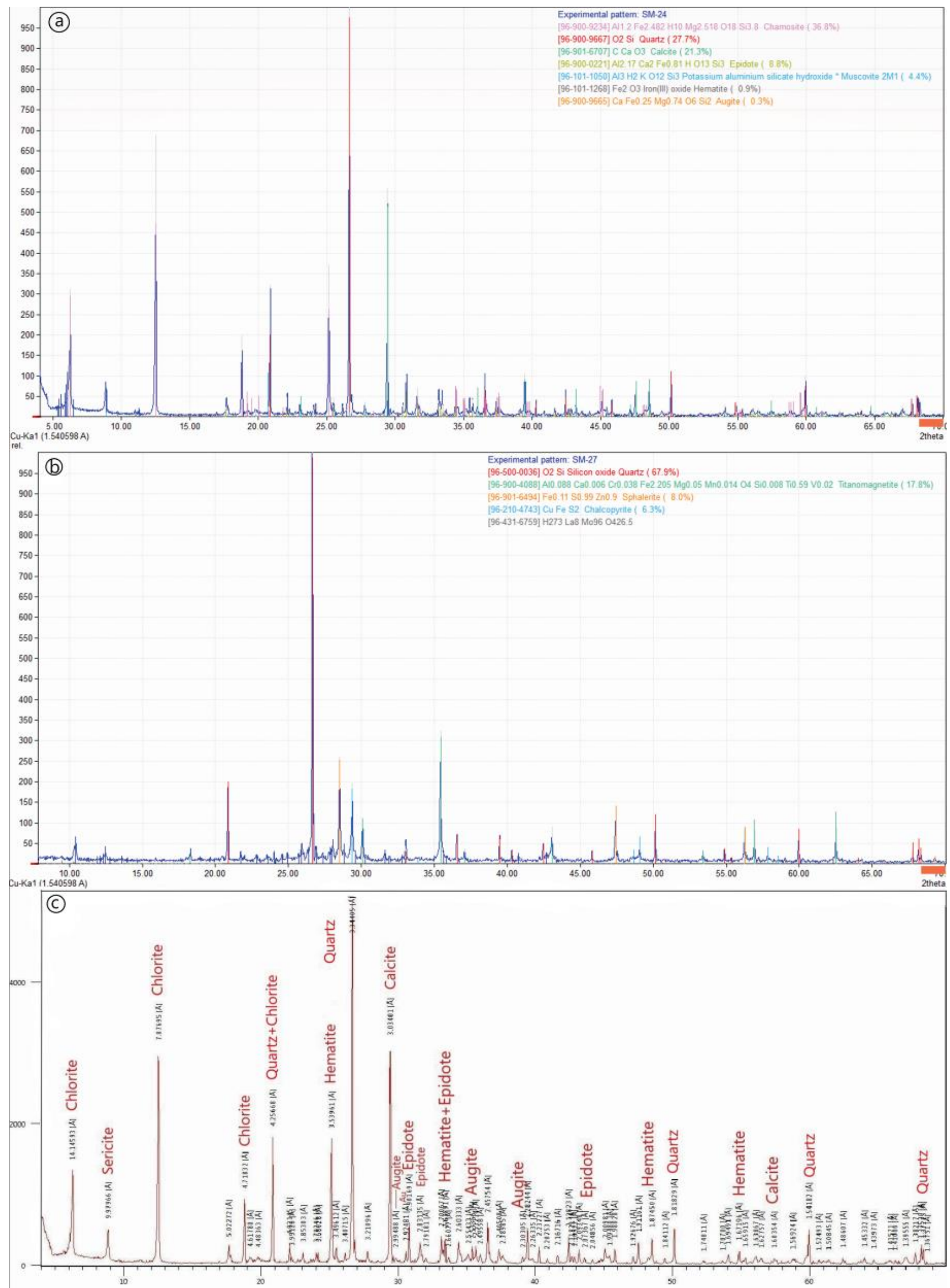

Figure 10. X-Ray diffractograms of Gadir $\mathrm{Au}-\mathrm{Ag}-\mathrm{Cu}-\mathrm{Pb}-\mathrm{Zn}$ mineralization 
and also phyllic alteration and advanced argillic alteration are defined as the main ore bearing zones for Gedabey $\mathrm{Au}-\mathrm{Ag}-\mathrm{Cu}$ deposit. The advanced argillic alteration minerals were determined as kaolinite, alunite, illite, pyrophyllite, and smectite in the Gedabey region. On the other hand, propylitic alteration represented by epidote and chlorite isclearly observed in the both deposits. Gadir $\mathrm{Au}-\mathrm{Ag}-\mathrm{Cu}-\mathrm{Pb}-\mathrm{Zn}$ mineralization associated with propylitic alteration and quartz \pm adularia \pm sericite veins. Additionally, silicification was observed in Gadir mineralization. Enargite and molybdenite are observed in Gedabey $\mathrm{Au}-\mathrm{Ag}-\mathrm{Cu}$ mineralization, although they are not observed in Gadir mineralization. The main factor of epithermal deposit for Gadir deposit is a quartz \pm adularia \pm sericite vein type mineralization Also, the main factors of high-sulfidation epithermal

\section{REFERENCES}

Anglo Asian Mining PLC. Ore Reserves Report Gadir Underground Mine. Anglo Asian Mining PLC Report. London, 2019, pp. 1117, https://www.angloasianmining.com/operations/overview/.

Baba-zade V.M., Mahmudov A.I., Ramazanov V.G. Copper and molybdenum porphyry deposits. Azerneshr. Baku, 1990, 375 p. (in Russian).

Babazadeh V., Veliyev A., Abdullayeva Sh.F., Imamverdiyev N., Mammedov S., Ibrahimov J., Bayramov A. New perspective gadir mineralization field in gedabey ore region. The Reports of National Academy of Sciences of Azerbaijan, 2015, Vol. LXXI, No 2, Baku, 2015, 8 p.

Bayramov A.A. Petrology and potential mineralization of Gedabek intrusion. Master Thesis, Baku State University, 2015, 75 p. (in Azerbaijani).

Bayramov A.A. Geological setting of the new discovering Gadir low sulfidation epithermal deposit, Gedabek ore district, Lesser Caucasus, Azerbaijan. IJISET - International Journal of Innovative Science, Engineering \& Technology, Vol. 4, 2016, 12 p.

İsmay1l C. Investigation of the geological, mineralogical, petrographical and geochemical properties of the Gedabek (West Azerbaijan) Au-Cu deposit. The Graduate School of Natural And Applied Science of Selçuk Unıversıty. Master Thesis, Konya, 2019, 92 p.

İsmayıl C., Arık F.,Özen Y. Preliminary geological and mineralogical features of Gedabek (Western Azerbaijan) $\mathrm{Au}-\mathrm{Cu}$ deposit. Engineering Sciences Journal of Omer Halisdemir University,Vol. 7, 2018, pp. 1153-1158.

İsmet A.R., Hasanov R.K., Abdullaev I.A., Bagirbekova O.D., Jafarova R.S., Jafarov S.A. Radiogeochronological study of geological formations of Azerbaijan. Nafta Press. Baku, 2003, 191 p. (in Russian).

Kerimov G.I. The mineralization and petrology of Gedabek ore cluster. Azerbaijan AS Publishing. Baku, 1963, 211 p. (in Russian).

Novruzov N., Valiyev V., Bayramov A., Mammadov S., Ibrahimov J., Ebdulrehimli A. Mineral composition and paragenesis of altered and mineralized zones in the Gadir low sulfidation epithermal deposit (Lesser Caucasus, Azerbaijan). Iranian Journal of Earth Sciences, Vol. 11, No. 1, 2019, pp. 14-29.

Sadıkhov E.A., Veliev A.A., Bayramov A.A., Mamedov S.M., Ibragimov D.R. Isotope geochemical characteristics (Sm$\mathrm{Nd}, \mathrm{Rb}-\mathrm{Sr}, \mathrm{S}$ ) and U-Pb SHRIMP II age of the Gedabek system for the Gedabey $\mathrm{Au}-\mathrm{Ag}-\mathrm{Cu}$ deposit are vuggy quartz, enargite and advanced argillic alterations. The mineralizations are mineralogically similar to each other except for a few features mentioned. While the mineral assemblages in the Gedabey mineralization suggest a high sulfidation, in Gadir mineralization - an epithermal ore deposit associated with a porphyry system. However, fluid inclusion analyzes that will have recently completed will lead to a more accurate suggestion.

\section{Acknowledgements}

The authors thank to Seljuk University for financial support of master thesis project (project number: 18201084) and anonymous reviewers for helpful comments.

\section{ЛИТЕРАТУРА}

Anglo Asian Mining PLC. Ore Reserves Report Gadir Underground Mine. Anglo Asian Mining PLC Report. London, 2019, pp. 1117, https://www.angloasianmining.com/operations/overview/.

Babazadeh V., Veliyev A., Abdullayeva Sh.F., Imamverdiyev N., Mammedov S., Ibrahimov J., Bayramov A.New perspective gadir mineralization field in gedabey ore region. The Reports of National Academy of Sciences of Azerbaijan, 2015, Vol. LXXI, No 2, Baku, 2015, 8 p.

Bayramov A.A. Geological setting of the new discovering Gadir low sulfidation epithermal deposit, Gedabek ore district, Lesser Caucasus, Azerbaijan. IJISET - International Journal of Innovative Science, Engineering \& Technology, Vol. 4, 2016, $12 \mathrm{p}$.

İsmay1l C. Investigation of the geological, mineralogical, petrographical and geochemical properties of the Gedabek (West Azerbaijan) Au-Cu deposit. The Graduate School of Natural And Applied Science of Selçuk Unıversıty. Master Thesis, Konya, 2019, 92 p.

İsmayıl C., Arık F., Özen Y. Preliminary geological and mineralogical features of Gedabek (Western Azerbaijan) $\mathrm{Au}-\mathrm{Cu}$ deposit. Engineering Sciences Journal of Omer Halisdemir University, Vol. 7, 2018, pp. 1153-1158.

Novruzov N., Valiyev V., Bayramov A., Mammadov S., Ibrahimov J., Ebdulrehimli A. Mineral composition and paragenesis of altered and mineralized zones in the Gadir low sulfidation epithermal deposit (Lesser Caucasus, Azerbaijan). Iranian Journal of Earth Sciences, Vol. 11, No. 1, 2019, pp. 14-29.

Singer D.A., Berger V.I., Moring B.C. Porphyry copper deposits of the World: Database and grade and tonnage models. U.S. Geological Survey Open-File Report 20081155, 2008, $45 \mathrm{p}$

Veliyev A., Bayramov A., Ibrahimov J., Mammadov S., Alizhadeh G. Geological setting and ore perspective of the new discovered Gadir low sulfidation epithermal deposit, Gedabek NW flank, Lesser Caucasus, Azerbaijan. Universal Journal of Geoscience, Vol. 6, No. 3, 2018, pp.78-101.

Bayramov A.A. Gədəbəy intruzivinin petrologiyası və potensial filizləşməsiş Magistr dissertasiyası. Bak1 Dövkət Universiteti , 2015, $75 \mathrm{~s}$.

Баба-заде В.М., Махмудов А.И., Рамазанов В.Г. Медно- и молибден-порфировые месторождения. Азернешр. Баку, 1990, 375 с. 


\title{
Geology and geophysics
}

intrusive (Azerbaijan). Regional Geology and Metallogeny, No.76, 2018, pp. 83-94 (in Russian).

Singer D.A., Berger V.I., Moring B.C. Porphyry copper deposits of the World: Database and grade and tonnage models. U.S. Geological Survey Open-File Report 2008-1155, 2008, 45 p.

Veliyev A., Bayramov A., Ibrahimov J., Mammadov S., Alizhadeh G. Geological setting and ore perspective of the new discovered Gadir low sulfidation epithermal deposit, Gedabek NW flank, Lesser Caucasus, Azerbaijan. Universal Journal of Geoscience, Vol. 6, No. 3, 2018, pp. 78-101.
Исмет А.Р., Гасанов Р.К., Абдуллаев И.А., Багирбекова О.Д., Джафарова Р.С., Джафаров С.А. Радиогеохронологические исследования геологических формаций Азербайджана. Nafta Press. Баку, 2003, 191 с.

Керимов Г.И. Петрология и рудоносность Кедабекского рудного узла. Изд. АН Азерб. ССР. Баку,1963, 211 с.

Садыхов А.Р., Велиев А.А., Байрамов А.А., Мамедов С.М., Ибрагимов Д.Р. Изотопно-геохимические характеристики (Sm-Nd, Rb-Sr, S) и U-Pb SHRIMP II возраст Гедабекского интрузива (Азербайджан). Региональная геология и металлогения, №. 76, 2018, с. 83-94.

\section{МИНЕРАЛОГИЧЕСКОЕ И РУДНО-ПЕТРОГРАФИЧЕСКОЕ СРАВНЕНИЕ ГЕДАБЕЙСКОГО И ГАДИРСКОГО МЕТОРОЖДЕНИЙ ГЕДАБЕЙСКОГО РАЙОНА (ЗАПАДНЫЙ АЗЕРБАЙДЖАН)}

\author{
Исмаил Дж'., Арик $\Phi^{2}$., Озен $\mathbf{E}^{3}$ \\ ${ }^{1}$ Технический университет Коньи, диссертант факультета инженерной геологии \\ 42250, Туриия, Конья, район Сельджуклу, ул.Рауфа Орбай, квартал Apдычлы: cosqun.ismayil1993@gтаil.com \\ ${ }^{2}$ Технический университет Коньи, профессор, доктор, декан факультета инженерной геологии \\ 42250, Туриия, Конья, район Сельджуклу, ул.Рауфа Орбай, квартал Ардычль \\ ${ }^{3}$ Технический университет Коньи, доктор факультета инженерной геологии \\ 42250, Турчия, Конья, район Сельджуклу, ул.Рауфа Орбай, квартал Ардычль
}

Резюме. Гедабейская рудная зона (Западный Азербайджан) расположена на Малом Кавказе. Рудообразование происходило в субдукционной зоне Лок-Гарабахской структурно-формационной зоны Тетического металлогенического пояса. Гедабейская рудная провинция является крупнейшим порфирово-эпитермальным рудным районом в стране. Вулканические породы и Гедабейский интрузив, под влиянием которого уплотнены вулканические породы, играют важную роль в процессе оруденения данного региона. Согласно предыдущим исследованиям вулканические породы Гедабейского рудного региона с содержанием риолита и риодацита относятся к байосскому возрасту, андезитовые туфы и андезитовые дациты - к батскому, а диориты и гранодиориты Гедабейского интрузива представляют верхнеюрский и нижнемеловой периоды. Магматизм Гедабейского рудного региона делится на три стадии: байоский, батский и верхнеюрский. Гедабейско-Биттибулагский глубинный разлом является самым важным, а также рудоконтролирующим фактором как Гедабейского $\mathrm{Au}-\mathrm{Ag}-\mathrm{Cu}, \mathrm{ta \kappa}$ и Гадирского $\mathrm{Au}-\mathrm{Ag}-\mathrm{Cu}-\mathrm{Pb}-\mathrm{Zn}$ месторождений в данном регионе. Целью данного исследования является сравнение минералого-петрографических особенностей Гедабейского $\mathrm{Au}-\mathrm{Ag}-\mathrm{Cu}$ и Гадирского $\mathrm{Au}-\mathrm{Ag}-\mathrm{Cu}-\mathrm{Pb}-\mathrm{Zn}$ месторождений с помощью петрографического, рудно-петрографического и рентген-дифрактометрического методов анализа. В рудах отмечаются халькопирит, сфалерит, галенит, пирит, золото, ковеллин, малахит, азурит и другие минералы.

Ключевые слова: Порфиро-эпитермальный, $A$ и-Ag-Cu-Pb-Zn руда, Гадир, Гедабей, Малый Кавказ

\section{GəDӘBӘY RAYONUNDA GӘDӘBӘY VӘ QӘDIR YATAQLARININ MINERALOJI VӘ FILIZ PETROQRAFIK TORKIBI (QӘRBI AZӘRBAYCAN)}

\author{
İsmayıl $\mathbf{C}^{\mathbf{1}}$, Arık $\mathbf{F}^{2}$, Özen $\mathbf{Y}^{\mathbf{3}}$. \\ ${ }^{1}$ Konya Texniki Universiteti, Geoloji Mühəndislik Şöbəsinin talabasi \\ 42250, Türkiya, Konya, Selçuklu rayonu, Rauf Orbay küç., Ardıçlı məhallasi: cosqun.ismayil1993@ gmail.com; \\ ${ }^{2}$ Konya Texniki Universiteti,Geoloji Mühandislik Şöbasinin rahbari, Professor, Doktor \\ 42250, Türkiya, Konya, Selçuklu rayonu, Rauf Orbay küç., Ardıçlı məhallasi; \\ ${ }^{3}$ Konya Texniki Universiteti, Geoloji Mühandislik Şöbasinin Doktoru \\ 42250, Türkiya, Konya, Selçuklu rayonu, Rauf Orbay küç., Ardıçlı məhəllasi
}

Xülasə. Gədəbəy (Qərbi Azərbaycan) filizləşmə zonası Kiçik Qafqaz bölgəsində yerləşir. Filizləşmə Tetis metallogenik kəmərinin Lök-Qarabağ struktur-formasiya zonası içərisində subduksiya zonasında əmələ gəlmişdir. Gədəbəy Azərbaycanın ən böyük porfir-epitermal filizləşmə sahəsi hesab olunur. Region haqqında bu günə qədər çox sayda fərqli tədqiqatçllar tərəfindən araşdırmalar aparılmışdır. Bölgədə Orta və Üst Yura yaşlı süxurlar geniş yayılmışdır. Regiondakı fillizləşmələrin əmələ gəlməsində vulkanik süxurların və Gədəbəy intruzivinin önəmli rolu var. Ovvəlki tədqiqatlara əsasən Gədəbəy filiz rayonundakı riolit və riodasit tərkibli vulkanik süxurlar Bayos yaşlı, andezit tufları və andezit dasitlər Bat yaşl1, Gədəbəy intruzivindəki diorit və qranodioritlər Üst YuraAlt Təbaşir yaşlı olduğu qeyd olunmuşdur. Gədəbəy filiz rayonunda magmatizm 3 etapa ayrılır: Bayos, Bat və Üst Yura mərtəbələri. Gədəbəy rayonunda həm Gədəbəy $\mathrm{Au}-\mathrm{Ag}-\mathrm{Cu}$ yatağının, həm də Qədir $\mathrm{Au}-\mathrm{Ag}-\mathrm{Cu}-\mathrm{Pb}-\mathrm{Zn}$ yatağının fillizənəzarət faktoru Gədəbəy-Bittibulaq dərinlik yarılmasıdır. Bu araşdırmanın məqsədi Gədəbəy $\mathrm{Au}-\mathrm{Ag}-\mathrm{Cu}$ və Qədir $\mathrm{Au}-\mathrm{Ag}-\mathrm{Cu}-\mathrm{Pb}-\mathrm{Zn}$ yataqlarının mineraloji-petroqrafik xüsusiyətlərini və hidrotermal dəyişilmə zonalarını petroqrafik, filiz- petroqrafik və XRD metodu ilə açıqlamaqdır. Filizlərdə içərisində xalkopirit, sfalerit, qalenit, pirit, qızıl, kovellin, malaxit, azurit və başqa minerallar qeyd edilmişdir.

Açar sözlor: Porfir-Epitermal, $\mathrm{Au}-\mathrm{Ag}-\mathrm{Cu}-\mathrm{Pb}-\mathrm{Zn}$ yată̆g, Qədir, Gədəbəy, Kiçik Qafqaz 